\title{
Management of Foreign Exchange Risks in a Selected Commercial Bank, in Nigeria
}

\author{
J.O. Adetayo, E.A. Dionco Adetayo and B. Oladejo
}

\section{INTRODUCTION}

When we talk about the growth and development of a nation's economy, hardly can there be any living soul that will not agree with me that the Spur Catalyst is the nation's bank. Conventionally the banking system was focused on receipts of deposits from customers on demand. But today the banking system has transcended beyond that scope, the system now incorporates the performance of other auxiliary functions such as financial advisory services, foreign exchange transaction of both domestic and international payment systems.

Focusing on foreign exchange, which is trading in foreign convertible currencies. It is an asset earned through exports of goods and services as well as the flow of foreign investments, external grants and loans. A favour-able nation, having balance of trade will have a stock of foreign exchange from which it can meet up its financial obligations to the outside world, including payment for goods and services, and even repayment of external loans and capital transfers. In fact a quantum of foreign exchange available at any point in time constitutes foreign exchange reserves, which is mainly held by the apex bank, Central Bank of Nigeria. Whereby other banks in Nigeria such as Commercial, Merchant and other specialised banks make requests for foreign exchange through bidding to satisfy their customers foreign exchange requirements.

The transaction in foreign exchange fall under the treasury operations of any legal bank. In treasury operation management, a sub-section of the unit is centred on treasury operations as a whole with a full range of services beyond cash management of which foreign exchange is among. Precisely the core of treasury functions is to see that banks offer comprehensive range of services to enrich the customer relationship at any point in time. Being that treasury functions cover a wider scope, it is undoubtedly subject to series of flaws that may hamper its ability to achieve the primal goals. In lieu of this view risk management cannot be swept under the carpet. Further more the ability to handle operation at an international level is crucial to any major financial institution. The same is also true about the need for automating the production and delivery of treasury services. For treasury activities to be effectively carried out, computers, communication and artificial intelligence must provide gateways to planning, execution and control. This statement is valid for subject that has financial implications which essentially means every issue that has undergone substantial evolution in response to changes in financial techniques, technological impact and market demand. There is for instance the need for comprehensive system of limit on all unmatched foreign exchange positions and for diversification of currency portfolio so as to ensure that potential losses from foreseeable exchanges rate are kept to a minimum. Such limits should incorporate system involving a number of separate limits covering such thing as daytime exposure limits, overnight limits, limits for currency, limits per individual transaction and limits settlement zones along with regular reporting and appraisal modalities.

The study delve into how the risk involved in foreign exchange can be effectively managed, by determining the following:

\section{Objectives}

1. to determine the various exchange risks which the treasurer of the selected bank is exposed to in its foreign exchange transaction

2. to investigate how these risks can be effectively managed and

3. to identify risk and exposure management techniques required for treasury management

\section{Hypothesis}

$\mathrm{H}_{0}$ : foreign exchange is not the life wire of any National Economy

$\mathrm{H}_{1}$ : foreign exchange is the life wire of any National Economy

$\mathrm{H}_{0}$ : foreign exchange risks are not impediments to the functions foreign 
exchange performs in the economy

$\mathrm{H}_{1}$ : foreign exchange risks are impediments to the functions foreign exchange performs in the economy

\section{Literature/Theoretical Framework}

The international monetary systems refer primarily to the set policies, institutions, practices, regulations and mechanisms that determine the rate at which each currency is exchange for another (Shapiro, 1999). Trading of currencies, international trade and investment. If there were a single international currency there would be no need for a foreign exchange market. The purpose of foreign exchange market is to enhance transfer of purchasing power dominated in one currency for another currency.

The foreign exchange market is not a physical place rather it is an electronically linked network of banks, foreign exchange brokers and dealers whose function is to bring together buyers and sellers of foreign exchange. It is not confined to any one country, but is dispersed throughout the leading financial centres of the world (Shapiro, 1991). Foreign exchange market consists, of two tiers, the Interbank market in which major banks trade with each other and the Retail market in which banks deal with their commercial customers (Redhead and Hughesis, 1988).

The major participants in the foreign exchange market are the large commercial banks, foreign exchange brokers in the interbank market, commercial customers primarily multi-national corporations and Central Banks which intervene from time to time in the market to smoothen exchange rate fluctuations or to maintain target exchange rates. Exchange rates represent the number of units of a given currency of one country that can be exchanged for unit of another currency (Van Horne, 1986).

Today foreign exchange has been the talk of the town, and this is because foreign exchange plays a very crucial role in the overall performance of the national economy. The practice of managing foreign exchange resources has therefore evolved broadly in line with the globalization and liberalization of economies and financial market. This has planed over such areas as risk management and active portfolio management. Broadly speaking foreign exchange is held and managed to facilitate international transactions. (Anifowoshe, 1997).

Consequently, some of the objectives which management of foreign reserve seek to achieve include security, liquidity, profitability and adequacy of the reserves.

Nwakwo, 1991, was of the opinion that foreign exchange major tasks is to ensure that the reserves are maintained at an adequate level to serve as cushion or buffer at times of temporary foreign short falls in foreign exchange receipt. In fact such a respite enables country to put its house in order and adopt necessary measures to deal with the external shock destabilising the Economy (Nwakwo, 1991).

Foreign exchange is a subset of external reserves but typically it constitutes the bulk of the reserves. In fact it is the component that is used on daily basis for settlement of international transactions hence foreign exchange management refers to the technique of efficient and optimal holding and deployment of the nations foreign exchange reserves to meet its external obligations and other economic objectives; as assigned by the Central Bank.

Indeed the consolidation of the external reserves holding in the CBN has foisted on the bank the challenges of adoptive and sharpening management skills that would ensure that the reserves are not only conserve but also optimally deployed for essential needs. This has over the years entailed designing ways of effectively monitoring the use of foreign exchange resources.

The use of trade and exchange controls as tools of reserve management involved comprehensive restrictions on trade and other international transactions. The main objectives here is to ensure that foreign exchange reserve, are conserved and adequate to guarantee external stability and that the available resources are optimally used to promote domestic production (Anifowoshe, 1997).

\section{Risk Management Policy and Strategies}

The fear of risk, the possibility of loss, injury, damage, peril or possibility that the actual outcome of an investment decision will not be the same as the forecasted result is inevitable in life. No aspect of human endeavour is devoid of or can escape it. It is inherent in everyday life and more so in the life of a banker. The bankers business has been and continues to be that of taking risks; which he does through maturity transformation - borrowing short and lending long. One can infer that the basis for doing this is 
the probability that he will not be called upon at any one time to redeem all his obligations provided he managed his affairs prudently. This implies having adequate capital and earnings and adequate liquidity to honour his obligation as and when they fall due. In congruous, it also means avoiding excessive risks. Risks that are taken must be compatible with profitability, liquidity are prudence (Nwankwo, 1991).

Thus if profitability is the foundation of banking then confidence is its cornerstone. If confidence collapses or is shattered, the whole edifice collapses and so will the bankers business. Managing risks, just like managing capital and liquidity is therefore a core function of banking and this has been increasingly so in the banking business for decades. The risk inherent in foreign exchange transactions is part of the risks a banker faces, in the 1950's attention was focused on techniques for the management of bank assets, while the 1960's and 1970's emphasized liability management. However, banking in the 1980's and 1990's shifted attention to risk, how to measure risk and how to control it for the betterment of the industry and its customers (Yahaya, 1997).

Essentially the over-riding consideration of bank management is the necessity to minimize risks and maximize returns, consistent with the prudential constraints and regulations. In reality the cardinal objective of a risk manager is to ensure that at the end of the day, he tries as much as possible to minimize his loss and maximize profit through efficient and effective management. Nwankwo (1991) posits that foreign exchange risk is probably the most involved of the banking risks. The risks involved are frequently not limited to losses due to unanticipated exchange rate changes. As each bank has to be in a position to meet its own foreign currency demand on time, there are liquidity risks and there are also interest rate risks; for dealings in the forward foreign exchange market. Since exchange rate movements correlate with movements in relative interest rate, a mismatched currency position and a mismatched inherent position may frequently not be independent.

Accordingly, most of the instruments and techniques for addressing these other risks particularly the interest rate risk are frequently used for managing foreign currency exposure risks (CBN Review, 1991).

With the expansion of treasurer's business activities, the need to adequately manage the associated exposure are becoming increasingly important. Some treasury functions today have introduced and others are planning to introduce an overall exposure monitoring and management system, able to integrate balance sheet and offbalance sheet business activities. This is done by consolidating all information elements relevant to risk and exposure offering a comprehensive view that facilitates control.

\section{METHODOLOGY}

The selected firm used for this study is a Commercial Bank of International Standard, located in Lagos, the business center of Nigeria. This bank has been in operation for over a decade serving both the domestic and International markets.

The principal activities of the bank include the following: corporate banking which focused on import and export financing, bills discounting, leases finance and funds transfer and International trade.

The study exploited both the primary and secondary sources of information. The primary source comprised of a structured questionnaires, to elicit pertinent responses from the respondents. The instrument used in this study is the questionnaires, which is divided into two parts: the first section centered on personal data of the respondents while the last section covered the area of risk management in foreign exchange. The nominal as well as the 5-point Likert scale were employed in the study. Data were collected from forty respondents who were stratifically and randomly selected out of seventy five employees on the basis that they were directly involved in both the International and Internal operations. The data for this study was not only gathered through primary source, secondary sources were also fully exploited. The data gathered were analysed and interpreted using the simple arithmetic, percentages and inferential statistics.

A non-parametric measure based on chisquare statistics was employed to test the hypothesis and determine if there is any association between foreign exchange trading and risk management issues. The chi-square value and p-value from a row by column table of data is based on the formula:

$$
\begin{aligned}
& \chi^{2}=\frac{\left.\sum_{(\mathrm{Oij}-} \sum_{\mathrm{ij}}\right)^{2}}{\sum_{i j}} \\
& d f=(r-1)(c-1) \text { degree of }
\end{aligned}
$$


freedom where Oij and Eij are the observed and expected frequencies in the ith row jth column in the row by column contingency table.

\section{RESULTS AND DISCUSSION}

Demographically the majority (75.0) percent of the respondents are not below bachelor's degree in education, while only 25.0 percent are professionals. (Table 1). Apparently, it is a clear indication that the staff members that are handling/assigned the responsibility of foreign exchange transactions are better positioned.

Table 1: Distribution of the respondents as to educational/professional qualifications

\begin{tabular}{lcc}
\hline \multicolumn{1}{c}{ Education } & $\begin{array}{c}\text { Frequency } \\
(f)\end{array}$ & $\begin{array}{c}\text { Percentages } \\
(\%)\end{array}$ \\
\hline Bachelors degree & 20 & 50 \\
Masters degree & 10 & 25 \\
Professional & & \\
Qualification & 10 & 25 \\
Total & 40 & 100 \\
\hline
\end{tabular}

Source: Survey 2001

\section{Foreign Exchange Risks and Management}

As we talk of foreign exchange risks, there are myriad of risks but the respondents pointed out the main risks that are principally foreign exchange based.

In table 2 , the high majority ( 90.0 percent) of the respondents were of the opinion that bank fraud is the most prevailing risk in the banking industry. While credit, interest rate and transaction had been rated next to fraud by the respondents with 75.0 percent respectively.

The moderate $(50.0 \%)$ number of respondents rated: transaction, economic; counter party, and money laundering as number 3 .

Table 2: Distribution of the respondents as to foreign exchange risks

\begin{tabular}{lcc}
\hline \multicolumn{1}{c}{ Types } & Frequencies & $\begin{array}{c}\text { Percentages } \\
\%\end{array}$ \\
\hline Transaction & 30 & 75 \\
Translation & 20 & 50 \\
Economic & 20 & 50 \\
Country & 10 & 25 \\
Counter party & 20 & 50 \\
Interest rate & 30 & 75 \\
Fraud & 36 & 90 \\
Credit & 30 & 75 \\
Money Laundering & 20 & 50 \\
\hline
\end{tabular}

Source: Survey 2001.
The functional staffs are exposed to risks arising from either payments or receipts of foreign exchange. In order to corroborate this, using Likert scaling technique the respondents were of the opinion that the exposure to risk was not only through payment and receipts. Thus calculated value is 80.1 , which is significantly higher than the table value of 9.488 at $5 \%$ level of significance.

To buttress the research study, a nonparametric measure based on one simple chisquare test was then employed to complement the percentage analysis. With one simple chisquare statistics the expected frequency gave 8 , ( 40 divided by 5 categories). From table III, the observed chi-square is larger than the chi-square table value. (80.1>9.488) at 4 degrees of freedom and at $5 \%$ level of significance. It can be inferred that the opinions of the respondents are significantly different, saying that the exposure to risk comes from other diverse areas.

Considering the exposure techniques and strategies; hedging technique was perceived by high majority $(70.0 \%)$ of the respondents to be very vital. (Table 3 ). Supporting the view, the calculated chi-square value of 76 is greater than the table value 9.488 at 4 degree of freedom and at 5\% level of significance. Thus the significantly difference is a clear indication that hedging is vital technique in risk and exposure strategy.

Avoidance of risk is a tool in foreign exchange risk management. Although people say avoidance of risk cannot be perfect, but in contrast the survey revealed that avoidance of risk completely is possible. This concept was perceived by 75.0 percent of the respondents. When the diverse opinion of the respondents were subjected to chi-square test, the calculated value 35.0 is greater than the table value 9.488 at 4 degree of freedom. Hence the respondents differ significantly in their opinion as to whether or not avoidance of risk is a tool of foreign exchange risk management.

Forecasting in exchange rates movement for profit is a strategy of foreign exchange risk management. A strong high majority (80.0 percent) of the respondent consented to this concept. In support of this, the calculated value 96.0 with its table value of 9.488 shows that respondent's opinion is significant at 5\% degree of significance. We can confidently say that forecasting in exchange rates movement is a strategy of foreign exchange risk management.

Spot transaction as a technique also minimizes 
foreign exchange risk; and in fact all $(100 \%)$ the respondents gave the opinion that spot transaction if not totally eradicate foreign exchange risk it would significantly reduce it.

Hence, the chi-square value of 76 is greater than the corresponding t. value $9.488\left(\chi^{2} \mathrm{c}>\chi^{2} \mathrm{t}\right)$. In this regard one can confidently conclude that spot transactions truly minimizes foreign exchange risk at $5 \%$ level of significance.

Protection against exchange rates fluctuation is another factor in exchange risk management. The observed frequency distribution shows that majority ( 90.0 percent) of the respondents strongly agreed that protection against exchange rate fluctuation is a key factor in foreign exchange risk management. The calculated value (124) is more than the t. value 9.488 at 4 degree of freedom and at $5 \%$ level of significance. Thus one is at least $95 \%$ sure that protection against exchange rate fluctuation is a factor in foreign exchange risk management.

Effective and efficient use of risk trading has been regarded as the best form of risk management as strongly perceived by 75.0 percent of the respondents. The calculated $\chi^{2} \mathrm{c}$ value 85.0 is greater than the $\chi^{2} \mathrm{t}$ value 9.488 from the chi- square distribution. Hence one can strongly $(95 \%)$ with confidence say that effective and efficient use of risk trading technique is the best form of risk management.

It is germane to crown the discussion on exposure techniques and risk management strategies by having a glance look at the invoicing in strong currencies as a factor in foreign exchange risk management.

As shown in aforementioned/preceded table III, the majority 75.0 percent of the surveyed respondents gave the opinion that invoicing in strong currencies is a factor in foreign exchange risk management. The calculated value $\chi^{2}$ c. 35.0 is highly significant, greater than $\chi^{2} \mathrm{t}=9.488$ at $5 \%$ level of significance.

Foreign exchange can be regarded as the life wire of a national economic growth and development but its risks are impediments to foreign exchange performance. A high majority (95.0 percent) of the respondents were of the opinion that foreign exchange risks are deterrent to foreign exchange performance, which may ginger economic development. The computed value $\chi^{2} \mathrm{c}=71$ at four degree of freedom and computed value $\chi^{2} \mathrm{t}=9.488$ at $5 \%$ level of

Table 3: Distribution of the respondents as to exposure techniques and risk management

\begin{tabular}{|c|c|c|c|c|c|c|c|c|c|c|c|c|c|}
\hline \multirow{2}{*}{\multicolumn{2}{|c|}{ Variables }} & \multicolumn{2}{|c|}{$S A$} & \multicolumn{2}{|c|}{$A$} & \multicolumn{2}{|c|}{$U$} & \multicolumn{2}{|c|}{$D$} & \multicolumn{2}{|c|}{$S D$} & \multirow[b]{2}{*}{$\chi^{2} c$} & \multirow[b]{2}{*}{$\chi^{2} t$ at 5} \\
\hline & & $O$ & $\bar{E}$ & $O$ & $E$ & $O$ & $E$ & $O$ & $E$ & $\bar{O}$ & $E$ & & \\
\hline 1 & $\begin{array}{l}\text { Exposure to risk is either } \\
\text { through payments or receipts }\end{array}$ & 30 & 8 & 8 & 8 & 2 & 8 & 0 & 8 & 0 & 8 & 80.1 & 9.488 \\
\hline \multirow[t]{9}{*}{2} & $\begin{array}{l}\text { Risk \& Exposure Techniques } \\
\text { and Strategies }\end{array}$ & & & & & & & & & & & & \\
\hline & a. Hedging & 28 & 8 & 12 & 8 & 0 & 8 & 0 & 8 & 0 & 8 & 76.0 & 9.488 \\
\hline & b. Avoidance of Risk completely & 0 & 8 & 10 & 8 & 20 & 8 & 0 & 8 & 10 & 8 & 35.0 & 9.488 \\
\hline & $\begin{array}{l}\text { c. Forescasting in exchange rates } \\
\text { movement for profit }\end{array}$ & 32 & 8 & 8 & 8 & 0 & 8 & 0 & 8 & 0 & 8 & 96.0 & 9.488 \\
\hline & d. Spot transactions & 28 & 8 & 12 & 8 & 0 & 8 & 0 & 8 & 0 & 8 & 76.0 & 9.488 \\
\hline & $\begin{array}{l}\text { e. Protection against exchange rate } \\
\text { fluctuations }\end{array}$ & 36 & 8 & 4 & 8 & 0 & 8 & 0 & 8 & 0 & 8 & 124 & 9.488 \\
\hline & f. Aggressive speculation & 28 & 8 & 12 & 8 & 0 & 8 & 0 & 8 & 0 & 8 & 76 & 9.488 \\
\hline & $\begin{array}{l}\text { g. Effective and efficient use of risk } \\
\text { trading techniques }\end{array}$ & 30 & 8 & 10 & 8 & 0 & 8 & 0 & 8 & 0 & 8 & 85 & 9.488 \\
\hline & h. Invoicing in strong currencies & 10 & 8 & 20 & 8 & 10 & 8 & 0 & 8 & & & 35 & 9.488 \\
\hline 3 & $\begin{array}{l}\text { Foreign exchange risks rate } \\
\text { impediments to foreign exchange } \\
\text { performance in the economy }\end{array}$ & 28 & 8 & 10 & 8 & 2 & 8 & 0 & 8 & 0 & 8 & 71 & 9.488 \\
\hline 4 & $\begin{array}{l}\text { Foreign exchange is the life wire } \\
\text { of any national economy }\end{array}$ & 32 & 8 & 8 & 8 & 2 & 8 & 0 & 8 & 0 & 8 & 96 & 9.488 \\
\hline 5 & $\begin{array}{l}\text { Role of information technology risk } \\
\text { in achieving foreign } \\
\text { exchange management }\end{array}$ & 0 & 8 & 38 & 8 & 0 & 8 & 2 & 8 & 0 & 8 & 133 & 9.488 \\
\hline
\end{tabular}

Key: SA - Strongly Agree, A - Agree, U - Undecided, D - Disagree, SD - Strongly Disagree, O - Ouserved Frequency, E - Expected Frequency

Source: Survey 2001. 
significance.

Borrowing a leave from the aforementioned statements one could hold that foreign exchange is the lifeblood of any economic development. The survey depicted that 80.0 percent of the respondents strongly concord with the concept. Today every body is talking about the evolution of information technology and its corresponding impacts on various ways of life particularly in commerce. In fact on this premise one cannot isolate foreign exchange from information technology. The survey further looked into the role of information technology in the achievement of a sound policy in risk management and trading techniques. As shown in table 3 , a high majority 95.0 percent of the respondents agreed that information technology played a vital role in the achievement of a sound risk management policy.

Further more effective risk management in foreign exchange is essential for the growth and survival of the National economy but unfortunately some mobid factors are perceived to be militating against it. Culled from table 4, 75.0 percent of the respondents gave the opinion that political is the main factor militating against effective risk management in foreign exchange. While only 25.0 percent of the respondents regarded economic to be the main factor militating against effective risk management.

Table 4: Factors militating against effective risk management in foreign exchange

\begin{tabular}{lcc}
\hline Factors & Frequency $(f)$ & Percentage $(\%)$ \\
\hline Political & 30 & 75.0 \\
Economic & 10 & 25.0 \\
\hline Total & 40 & 100.0 \\
\hline Source: Survey & 2001. &
\end{tabular}

Apart from the aforementioned factors the inconsistent government policies on foreign exchange can be viewed as a deterrent to the foreign exchange risk management. As shown in table 5, the majority (90.0 percent) of respondent were of the opinion that persistent and inconsistent government policies in foreign exchange is a significant factor in foreign exchange risk management. The calculated $\chi^{2} \mathrm{c}=$ 124 at 4 d.f. and $\chi^{2} t=9.488$ at $5 \%$ level of significance. Apparently the calculated value $\chi^{2} \mathrm{c}>\mathrm{x}^{2} \mathrm{t}$ which is a clear indication that inconsistent policies is a deterrent, and harmful tool to foreign exchange risk management.

In table 6 , the calculated value $\chi^{2} \mathrm{c}=64.8$ greater than the corresponding table value $\chi^{2} \mathrm{t}=$
Table 5: Distribution of the respondents as to in consistent Government policies

\begin{tabular}{lcccc}
\hline \multicolumn{1}{c}{ Scale } & $\begin{array}{c}\text { Observed } \\
\text { frequency } \\
(0)\end{array}$ & $\begin{array}{c}\text { Expected } \\
(f) E\end{array}$ & $O-E$ & $\begin{array}{c}0-E^{2} \\
E\end{array}$ \\
\hline Strongly Agree & 36 & 8 & 28 & 98 \\
Agree & 4 & 8 & -4 & 2 \\
Undecided & 0 & 8 & -8 & 8 \\
Disagree & 0 & 8 & -8 & 8 \\
Strongly Disagree & 0 & 8 & -8 & 8 \\
\hline
\end{tabular}

Survey: 2001

$\chi^{2} \mathrm{C}=124$, 4df $\chi^{2} \mathrm{t}=9.488$.

7.815 at 3 degree of freedom and at $5 \%$ level of significance. Thus we are $95 \%$ confident that management's attitude to foreign exchange risk is that of risk averse. An efficient management of foreign exchange risk is just like wining a gold medal in Olympic game, because of its positive corresponding effects on the national economic development. And in fact a nation regardless of its economic status cannot neglect or negate the importance of the badly needed foreign exchange, which is regarded as the "life wire" of a nation's Table 6: Management attitude to foreign risks

\begin{tabular}{lcccr}
\hline Variable & $\begin{array}{c}\text { Observed } \\
\text { frequency } \\
(0)\end{array}$ & $\begin{array}{c}\text { Expected } \\
(f)\end{array}$ & $\begin{array}{l}\text { O- } E \\
E\end{array}$ & $\begin{array}{c}\text { O- } E^{2} \\
E\end{array}$ \\
\hline Risk Averse & 32 & 10 & 22 & 48.4 \\
Aggressive & 4 & 10 & -6 & 3.6 \\
$\begin{array}{l}\text { Speculation } \\
\text { Risk Neutral }\end{array}$ & 2 & 10 & -8 & 6.4 \\
$\begin{array}{l}\text { Participation } \\
\text { only where }\end{array}$ & 2 & 10 & -8 & 6.4 \\
it is for \\
profit
\end{tabular}

economy.

This concept was corroborated by high majority ( 80.0 percent) of the respondents who strongly agreed that foreign exchange is the core of any national development. (Table 7). Inferred from table VII; the calculated value $\chi^{2} \mathrm{c}=96.0$ at 4 degree of freedom is much greater than the table value $\chi^{2} \mathrm{t}=9.488$ at $5 \%$ level of significance. Relatively, it confirmed the assertion that foreign exchange serves as the life wire of any national economy.

\section{CONCLUSIONAND RECOMMENDATIONS}

From the findings of this study, it is obvious that risk management cannot be swept under the 
Table 7: Foreign Exchange as life wire of any National Economy

\begin{tabular}{lcccc}
\hline Variable & $\begin{array}{c}\text { Observed } \\
\text { frequency } \\
(0)\end{array}$ & $\begin{array}{c}\text { Expected } \\
(f)\end{array}$ & $0-E$ & $\begin{array}{c}0-E^{2} \\
E\end{array}$ \\
\hline Strongly Agree & 32 & 8 & 24 & 72 \\
Agree & 8 & 8 & 0 & 0 \\
Undecided & 0 & 8 & -8 & 8.0 \\
Disagree & 0 & 8 & -8 & 8.0 \\
Strongly Disagree & 0 & 8 & -8 & 8.0 \\
\hline
\end{tabular}

Survey: 2001

$\chi^{2} \mathrm{C}=96.0$, 4df $\chi^{2} \mathrm{t}=9.488$ (5\% level).

carpet; for it is one of the major catalysts to national development.

The research also revealed that the exposure to risk comes from other diverse areas; such as avoidance of risk, forecasting in exchange rates movement for profit, spot transaction, protection against exchange rates fluctuation and effective and efficient use of risk trading.

Stringent control measures and administrative bottle necks of the Central Bank of Nigeria are considered as the major factors hindering the achievement of sound exchange policies.

Conclusively foreign exchange can be regarded as the life wire of a national economic growth and development and even the life blood of any economic development.

Based on this study the following recommendations are made:

* That information technology should be imposed in the achievement of a sound policy in risk management and trading techniques

* That government should be consistent in all policies concerning foreign exchange

* That government should try to have an efficient management of foreign exchange risk for national economic growth.

* Furthermore the government should step up vigorously the low and declining productive activity by boosting other sectors of the economy so that more foreign exchange could earned through these sources and made available to the banks.

There is also need to modify the facility of foreign exchange utilization so as to channel more of the available foreign exchange resources from non productive to productive purposes.
Government should put in place effective measures to arrest capital flight and attract foreign investment and capital inflows.

\section{KEYWORDS Economy; development; domestic and foreigh currencies; management}

ABSTRACT Banks are regarded as the bed rock of a nation's economy, they are the harbinger of economic development through a prudent management of both domestic and foreign currencies. This survey was carried out in an old generation bank that is fully engaged in transaction of foreign exchange. The study primarily looks into the management of foreign exchange risks, and the impact of these risks on foreign exchange transactions. The study exploited both the desk and primary sources of information, a structure questionnaire was designed to gather pertinent data from 40 respondents that are stratifically and randomly selected. The data gathered were analysed and interpreted using the simple arithmetic, percentages and inferential statistics. The result revealed that bank fraud is most $(90.0 \%)$ prevailing risk in the banking industry. Considering the exposure techniques and strategies, hedging technique was perceived to be a very vital technique in risk and exposure strategy. $x^{2} c=76>x^{2} t=9.88$

Spot transaction technique was founded to be effective in minimizing foreign exchange risk. Furthermore, the effective and efficient use of risk trading has been regarded as the best form of risk management. In order to crown it all, invoicing in strong currencies was revealed to be a factor in foreign exchange risk management. The persistent and inconsistent policies of the government in foreign exchange is a deterrent to the foreign exchange risk management.

$\left(x^{2} c=124\right.$ at 4 d.f, $x^{2} t=9.488$ at $5 \%$

level significance; $\left.x^{2} c>x^{2} t\right)$

\section{REFERENCES}

Anifowoshe C.A. 1997. Management of Foreign Exchange: A Peep into the next decade. Nigeria. Ballion, Vol. 21 No. 4, Oct/Dec.

CBN Review. 1991. Annual Reports and Statement of Accounts. Various Issues.

Nwankwo G.O. 1991. Bank Management Principles and Practice. UK: Malthouse Press Limited

Radhead K. and S. Hughes. 1988. Financial Risk Management. India: Sower Publishing Company Ltd. pp. $1-24$.

Shapiro A.C. 1991. Multinational Financial Management. India: Prentice Hall, Private Ltd. $4^{\text {th }}$ Edition, pp. 33-45.

Van Horne J.C. 1986. Financial Management and Policy. Prentice Hall, New Jersey: International $7^{\text {th }}$ Edition, pp. 717-725.

Yahaya M.I. 1997. Prospects and Challenges of Banking in Nigeria in the $21^{\text {st }}$ Century, New Nigeria Newspaper, August $6^{\text {th }}$.

Authors' Address: J.O. Adetayo, E.A. Dionco Adetayo and B. Oladejo, Department of Management and Accounting, Obafemi Awolowo University, Nigeria 